\title{
Program for Managing the E-Area Performance Assessment Models for Slit Trenches and Engineered Trenches
}

Prepared by:

L. B. Collard

December 3, 2002

Rev. 0

Westinghouse Savannah River Company

Savannah River Site

Aiken, SC 29808

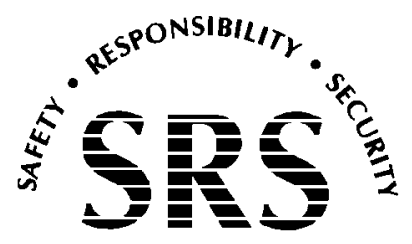

SAVANNAH RIVER SITE

Prepared for the U.S. Department of Energy Under

Contract Number DE-AC09-96SR18500 
This document was prepared in conjunction with work accomplished under Contract No. DE-AC09-96SR18500 with the U. S. Department of Energy.

\section{DISCLAIMER}

This report was prepared as an account of work sponsored by an agency of the United States Government. Neither the United States Government nor any agency thereof, nor any of their employees, makes any warranty, express or implied, or assumes any legal liability or responsibility for the accuracy, completeness, or usefulness of any information, apparatus, product or process disclosed, or represents that its use would not infringe privately owned rights. Reference herein to any specific commercial product, process or service by trade name, trademark, manufacturer, or otherwise does not necessarily constitute or imply its endorsement, recommendation, or favoring by the United States Government or any agency thereof. The views and opinions of authors expressed herein do not necessarily state or reflect those of the United States Government or any agency thereof.

This report has been reproduced directly from the best available copy.

Available for sale to the public, in paper, from: U.S. Department of Commerce, National Technical Information Service, 5285 Port Royal Road, Springfield, VA 22161, phone: (800) 553-6847, fax: (703) 605-6900

email: orders@ntis.fedworld.gov

online ordering: http://www.ntis.gov/help/index.asp

Available electronically at http://www.osti.gov/bridge

Available for a processing fee to U.S. Department of Energy and its contractors, in paper, from: U.S. Department of Energy, Office of Scientific and Technical Information, P.O. Box 62, Oak Ridge, TN 37831-0062,

phone: (865)576-8401,

fax: (865)576-5728

email: $\underline{\text { reports@ adonis.osti.gov }}$ 
TABLE OF CONTENTS

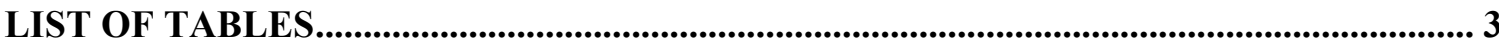

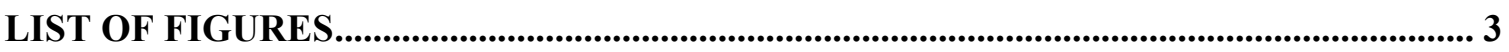

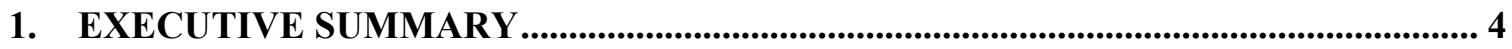

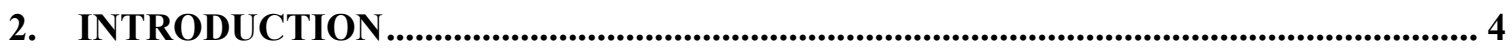

3. PERFORMANCE ASSESSMENT CONTROLS..................................................... 4

4. FRAMEWORK FOR TRENCH GROUNDWATER MODEL ANALYSES .................. 5

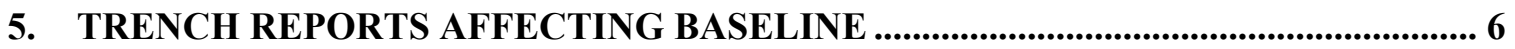

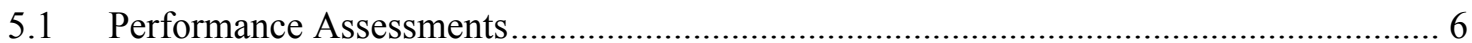

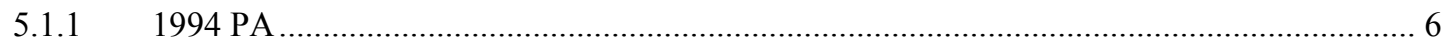

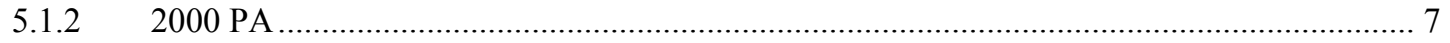

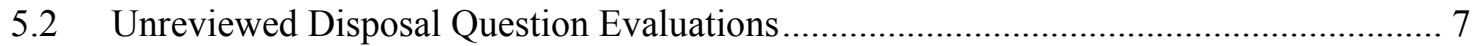

5.2.1 UDQ-E for Job Control Waste in Slit Trenches ……...................................................... 7

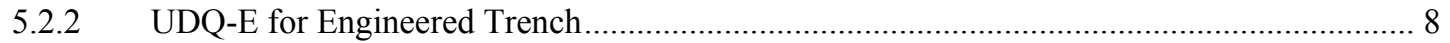

5.2.3 UDQ-E for ETF Carbon Vessel Disposal in Trenches ……................................................. 8

5.2.4 UDQ-E's for Trench Geometry Deviations ................................................................. 8

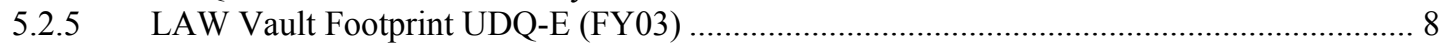

5.2.6 UDQ-E for Evaluation of M-Area Glass (FY03) ……...................................................... 8

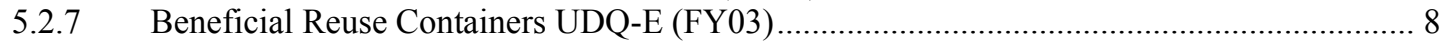

5.2.8 UDQ-E to Evaluate backfill hydraulic properties (FY03) .................................................. 8

5.2.9 UDQ-E to Evaluate the disposal of Co-60 slugs placed in a DU cask (FY03)....................... 8

5.2.10 UDQ-E for Engineered Trench \#2 Location (FY03) ....................................................... 8

5.2.11 UDQ-E for change in closure concept from kaolin layer to geosynthetic clay liner (GCL)

(FY03) 9

5.2.12 UDQ-E to Potentially evaluate disposal of Cf-252 waste (FY03) ……............................... 9

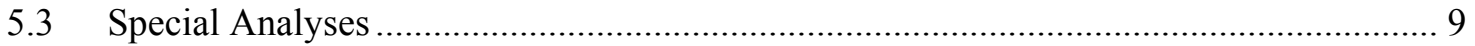

5.3.1 M-Area Glass Special Analysis ................................................................................ 10

5.3.2 Slit Trench High-Concentration I-129 Special Analysis ………….................................... 10

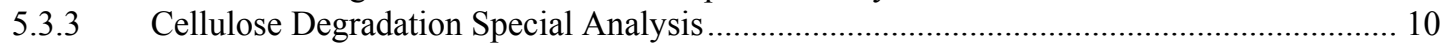

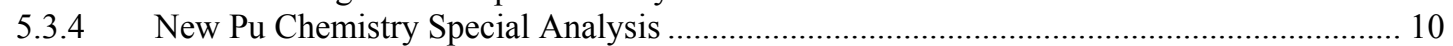

5.3.5 Correction and Update of Disposal Limits Special Analysis................................................ 10

5.3.6 Area Source for Air Emissions as Part of the K and L Basin Resins Special Analysis (FY03) 10

5.3.7 Special Analysis for disposal of three ETF Activated Carbon Vessels in trenches (FY03) . 10

5.3.8 Special Analysis to implement timing of doses to calculate sums-of-fractions (FY03) ....... 10

5.3.9 Special Analysis to set new Pu trench/vault limits (FY03) ............................................... 10

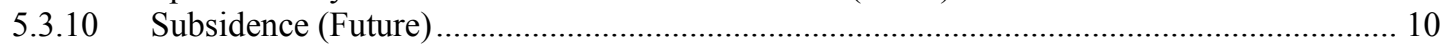

5.3.11 Incorporation of important results from other studies (Future) ............................................ 11

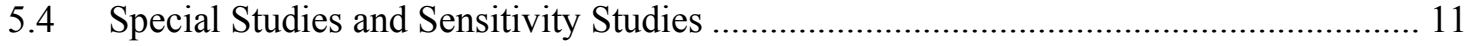

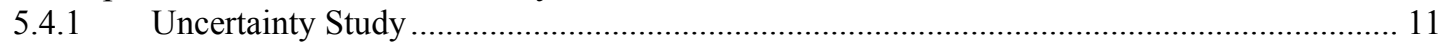

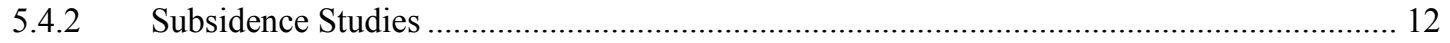

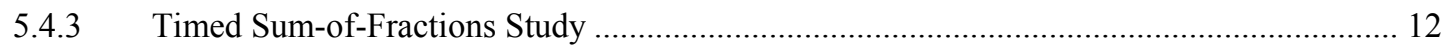

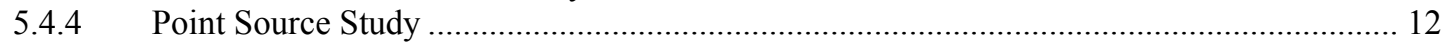

5.4.5 Vadose Zone vs. Aquifer Footprint Independent Report................................................... 12

5.4.6 Incorporate vadose zone data in a three-dimensional trench model (FY03)......................... 12

5.4.7 Aquifer Source and Observation Cell Location Special Study (FY03) ................................ 12

5.4.8 Point Source Special Study (FY03) .................................................................................... 12

5.4.9 Model waste layer stabilization and long term cover systems for the engineered trench.

(Future) 13

5.4.10 Numerical Dispersion Study (Future) 


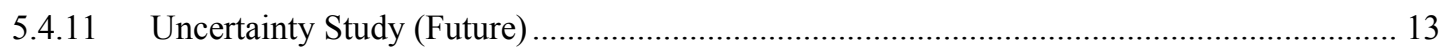

REFERENCES ..................................................................................................................................... 14

\section{List of Tables}

Table 1. Changes to the Baseline Model Evaluated in UDQ-Es ............................................... 7

Table 2. Changes to the Baseline Model Evaluated in Special Analyses ..................................... 9

Table 3. Changes to the Baseline Model Evaluated in Special Studies................................... 11

\section{List of Figures}

Figure 1. Dependencies between Trench Groundwater Model Analyses................................... 6 


\section{Program for Managing the E-Area Performance Assessment Models for Slit Trenches and Engineered Trenches}

\section{Executive Summary}

The baseline performance assessment (PA) slit trench model has become more important as more low-level waste streams are disposed in Slit Trenches and the Engineered Trench. Since the 2000 E-Area Low-Level Waste Facility (LLWF) PA revision was issued new waste streams, changes in disposal operations, new information, and modeling improvements have been evaluated with slit trench models. This white paper describes those analyses and modifications to the baseline slit trench model for each analysis. These evaluations are summarized in Tables 1 through 3 for Unreviewed Disposal Question Evaluations (UDQ-Es), Special Analyses and Special Studies, respectively.

The system for controlling changes to our baseline has been improved in several ways. A quality assurance plan (Collard, 2002d) has been issued for the Porflow computer program. Porflow has been placed under configuration control. In FY03, baseline model data reports will be issued to help provide configuration control on the models. Additionally in FY03 a PA position paper will be prepared that specifies the approach and controls for implementing baseline model improvements.

\section{Introduction}

Trench disposal has graduated from suspect soil to multiple waste streams, because of improved PA models, vadose zone monitoring and waste-specific characterization data. This increase in the variety of waste being disposed in trenches has lead to multiple models being developed that need to be managed in a systematic manner that considers all the waste streams. This document describes the program for managing these changes. An overview of past and present analyses identifies the objectives of those analyses and their relationships with the 2000 PA (McDowell-Boyer, et al., 2000) slit trench model that serves as a baseline. Specifically this document accomplishes the following:

- Describes the current system of performance assessment controls and how those controls have changed with time

- $\quad$ Presents the overall structure and relationships between the different trench groundwater model components

- Provides a framework showing how the baseline slit trench model was used in previous and current work organized by document category

This document addresses the following types of disposal facilities for very-low-activity waste:

- $\quad$ slit trenches

- $\quad$ engineered trenches

This document does not address the following types of disposal facilities:

- LAW vaults

- ILV vaults

- $\quad$ intimately-mixed cement-stabilized waste disposal trenches

- disposal trenches for cement-stabilized encapsulated waste (components-in-grout, CIG)

- naval reactor waste pads.

\section{Performance Assessment Controls}

Controls to ensure that PA-derived disposal limits are not exceeded have evolved since the E-Area LLWF PA (1994) was first developed. Initially, radionuclide inventory and concentration limits were derived in the PA for each performance measure (e.g., intruder, groundwater protection). These limits were applied without regard to the differing performance measures or time frames for which the limit was calculated (i.e., the most restrictive of the set of limits calculated for each radionuclide was applied). This set of limits was incorporated into a computerized Waste Information and Tracking System (WITS) to provide a means for Solid Waste Operations to ensure that individual waste packages conformed to the limits. These controls were effective, but did not integrate the PA process into SW Operations. 
To more effectively integrate the PA process into SW Operations, a more disciplined system of controls was needed. Thus, a system of UDQ-Es to evaluate proposed or discovered changes versus the PA and Special Analyses to extend the PA (i.e., calculate new limits) was implemented. This system facilitates technical consideration of situations (e.g., unusual waste forms, new waste streams, changes in trench construction) to determine whether they are bounded by the existing PA or whether additional PA calculations (i.e., Special Analysis) are needed. Special studies (e.g., sensitivity studies) are sometimes warranted as an intermediate analysis before implementing changes to limits or new disposal practices. This system has enabled the expansion of the use of trenches for much of the SRS LLW.

The system of controls will continue to evolve to reduce conservatism in disposal limits and improve our ability to manage baseline changes. Several improvements are planned for FY03:

- PA position paper

- Baseline data reports

- Configuration control of models

A PA Position Paper will be prepared in FY03 to examine the issues of baseline improvements. Special Analyses, UDQ Evaluations and Special Studies being undertaken this year are expected to show PA results to be either potentially conservative or non-conservative depending upon the issue being addressed. These potential changes to PA baseline models and resulting impacts on limits need to be managed in a way that minimizes disruption to SW Operations and minimizes PA costs. The PA Position Paper will specify how the baseline is defined, and changes managed with a focus on FY03-04 studies.

The baseline itself consists of the input files for computer models. In FY03 baseline files will be described by a series of data reports for disposal units, as appropriate. Each data report will include physical and chemical input parameters, initial and boundary conditions and configuration information for a specific disposal unit model. When the baseline is modified, the data report will be updated to include the modifications.

The baseline model is assumed to be the input files for the 2000 PA computer analyses for slit trenches. The baseline files currently are maintained on analysts' computers, generally with backup copies placed on CD-ROMs that are retained by the author of the Special Analysis, PA, or other document. In FY02 a software quality assurance plan was developed for the PORFLOW code. A shift to place the baseline files under more rigorous configuration control through use of an electronic software library is being initiated in FY03.

\section{Framework for Trench Groundwater Model Analyses}

The trench groundwater model consists of eight major analyses (see Figure 1) that interact with each other. Analyses are either steady-state flow analyses (presented on the left side of Figure 1) or transport analyses (presented on the right side of Figure 1). Each flow analysis feeds information to its associated transport analysis. Furthermore, the vadose zone transport analyses feed information in the form of the contaminant flux to the water table to the aquifer transport analysis.

In the vadose zone three cap stages require analysis. Initially an uncapped trench is assumed to exist for 25 years during operations. At 25 years the trench is assumed capped. The cap is assumed to remain intact during 100 years of institutional control, i.e., until 125 years after the assumed start of operations.

Immediately at the end of institutional control the cap is assumed to fail and to remain in that state for the remainder of the analysis period, or 10,000 years after the assumed start of operations.

In summary, the vadose zone model consists of three steady-state flow analyses and three transport analyses. The aquifer model consists of one steady-state flow analysis and one transport analysis. Each of these analyses forms an integral part of a base case. 


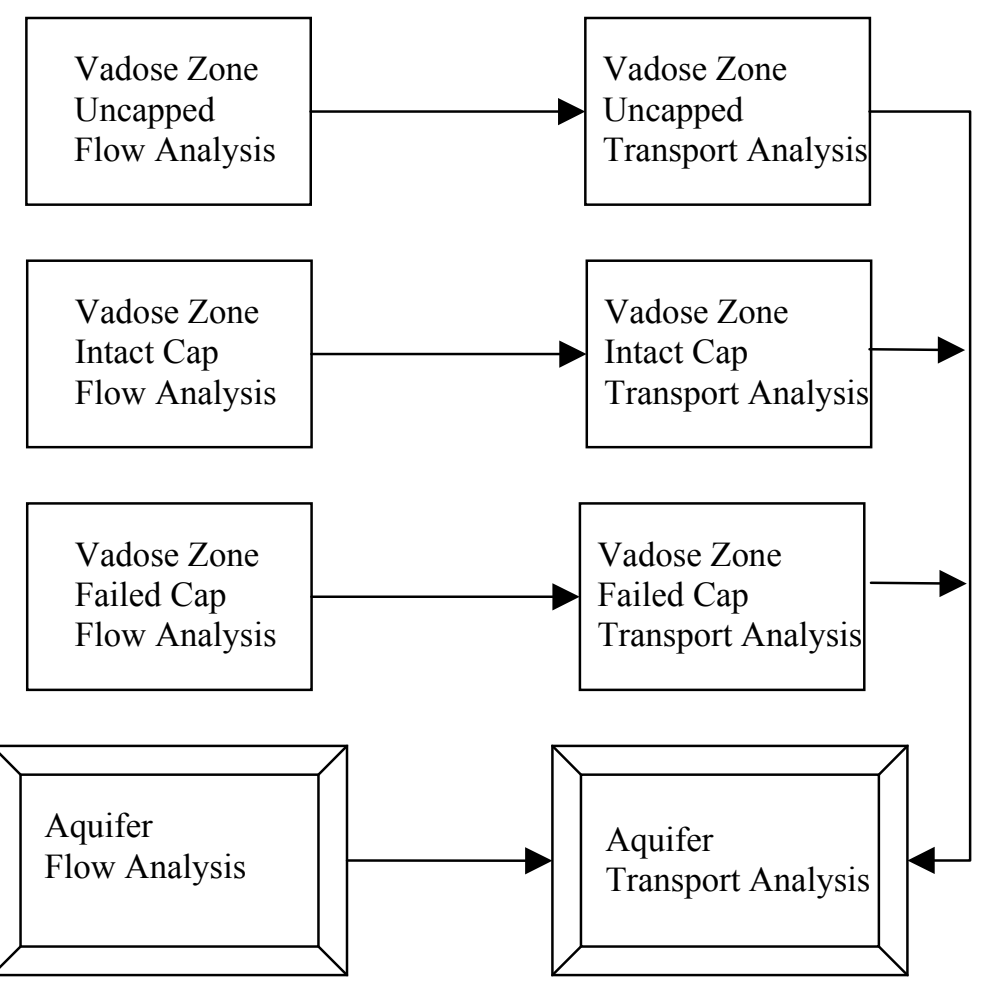

Figure 1. Dependencies between Trench Groundwater Model Analyses

\section{Trench Reports affecting Baseline}

\subsection{Performance Assessments}

Two PAs for the E-Area LLWF have been issued, the first in 1994 and the second in 2000.

\subsubsection{PA}

In the original 1994 PA (Martin Marietta Energy Systems, Inc. and EG\&G Idaho, Inc., 1994) five trenches were proposed for disposing suspect soil. The trenches were assumed to be " $6 \mathrm{~m}$ wide by $200 \mathrm{~m}$ long by 6 $\mathrm{m}$ deep." The suspect soil was "assumed to be placed in the trenches to a depth of $4.8 \mathrm{~m}$, allowing for 1.2 $\mathrm{m}$ of a clean soil cover in the trenches." The five trenches were arranged parallel in the long direction. They spanned a total width of $48 \mathrm{~m}$ between the outside edges of the outermost trenches. The five trenches occupied a combined waste width of $30 \mathrm{~m}$, thus the 4 gaps between the trenches occupied a combined unused width of $18 \mathrm{~m}$ or $4.5 \mathrm{~m}$ per gap.

The original model (1994 PA: Figure I.2-1) showed a cap about $500 \mathrm{~cm}$ thick above the clean soil cover. Key values derived from the Porflow input file (1994 PA: page I-43) are as follows:

- Distance from the surface to the top of waste is $15.58 \mathrm{ft}$

- Distance from the bottom of waste to the water table is $29.45 \mathrm{ft}$

- Distance from the left side of waste to the left edge of the model is $323.98 \mathrm{ft}$

- Distance from the right side of waste to the right edge of model is $323.98 \mathrm{ft}$

- Thickness of waste is $20.59 \mathrm{ft}$

- Length of waste is $664.37 \mathrm{ft}$ (the length was modeled rather than the width)

- Thickness of clean soil cover is $8.2 \mathrm{ft}$

For this model, a vertical cross-section oriented parallel to the long axis of the trench was employed. 


\subsubsection{PA}

For the 2000 PA model (McDowell-Boyer, et al., 2000), the orientation of the vertical cross-section was rotated to be parallel to the short axis of the trench. This model is the baseline for all future models.

In the 2000 PA report the five trenches proposed for disposing suspect soil increased to two sets of five trenches for disposing a variety of wastes. The trench dimensions were $6 \mathrm{~m}$ wide by $200 \mathrm{~m}$ long by $6 \mathrm{~m}$ deep. The waste had a depth of $4.8 \mathrm{~m}$.

The 2000 PA model (2000 PA: Figure 4.3-7) showed a cap above the clean soil cover ranging from $9 \mathrm{ft}$ thick at the left edge of the model to $8 \mathrm{ft}$ thick at the right edge of the model. Key values derived from the Porflow input file on a CD-ROM are as follows:

- Distance from the surface to the waste top ranges from $13.9 \mathrm{ft}$ to $13.5 \mathrm{ft}$ from left to right

- Distance from the bottom of waste to the water table is $26 \mathrm{ft}$

- Distance from the left side of waste to the left edge of model is $5 \mathrm{ft}$

- Distance from the right side of waste to the right edge of the model is $25 \mathrm{ft}$

- Thickness of the waste is $15 \mathrm{ft}$

- Width of the waste and trench is $20 \mathrm{ft}$

- Thickness of the clean soil cover is $5 \mathrm{ft}$

\subsection{Unreviewed Disposal Question Evaluations}

UDQ-E's examine the application of the PA to scenarios not explicitly stated in the PA. They can determine that the PA bounds the scenario or that a Special Analysis is needed to establish new limits. UDQ-Es affecting trench disposal are described below. Changes to the baseline model evaluated in these UDQ-Es are summarized in Table 1.

Table 1. Changes to the Baseline Model Evaluated in UDQ-Es

\begin{tabular}{lll}
\hline Description & Baseline Value & Study Value \\
\hline Job Control Waste & \multicolumn{1}{c}{ Past UDQ-Es } & Waste form of job control waste \\
\hline Engineered Trench & Set of 5 slit trenches & $\begin{array}{l}\text { 1 Eng. Trench with same } \\
\text { footprint as 5 slit trenches }\end{array}$ \\
\hline ETF Carbon Vessel & Literature Kd, open vessel & Waste-specific Kd, sealed vessel \\
\hline Trench geometry deviations & Nominal geometry & $\begin{array}{l}\text { Length, depth, width changes of } \\
\text { over 10 percent }\end{array}$ \\
\hline & \multicolumn{1}{c}{$F Y 03$ UDQ-Es } & \\
\hline LAW Vault Footprint & $\begin{array}{l}\text { Inconsistently reported } \\
\text { dimensions }\end{array}$ & Consistent set of dimensions \\
\hline Evaluation of M-Area Glass & Glass beads and strings & Melter, debris and components \\
\hline Beneficial Reuse Containers & Non-activated waste & Activated metal \\
\hline Backfill hydraulic conductivity & $\begin{array}{l}\text { Controlled, compacted backfill } \\
\text { value }\end{array}$ & $\begin{array}{l}\text { Typical uncontrolled backfill } \\
\text { value }\end{array}$ \\
\hline Co-60 slugs placed in a DU cask & Low potential inventory screened & Higher inventory \\
\hline Engineered Trench \#2 Location & Original location & Different location and flow field \\
\hline $\begin{array}{l}\text { Replace cap kaolin layer with } \\
\text { geosynthetic clay liner (GCL) }\end{array}$ & Kaolin layer & GCL \\
\hline Cf-252 waste & Low potential inventory screened & Higher inventory \\
\hline
\end{tabular}

\subsubsection{UDQ-E for Job Control Waste in Slit Trenches}

The only slit trench waste forms considered in the original (1994) PA were soil, rubble and wood suspected of being contaminated with radioactive material. The UDQ-E (Wilhite, 2000b) provided a bridge from the 1994 PA waste acceptance criteria to the 2000 PA waste acceptance criteria by extending the PA to include job control waste and other waste forms. 


\subsubsection{UDQ-E for Engineered Trench}

A UDQ-E (Wilhite, 2000a) was prepared to establish whether the PA applied to an Engineered Trench. The Engineered Trench was considered to have the same footprint as a set of five slit trenches. The UDQ-E determined that the PA did apply to the Engineered Trench and that its inventory limits were identical to those for a set of five slit trenches. The Engineered Trench has a greater waste disposal area than does a set of five slit trenches because of clean buffer space between the slit trenches. The same inventory limit spread over a greater waste disposal area creates smaller allowable concentrations for the Engineered Trench.

\subsubsection{UDQ-E for ETF Carbon Vessel Disposal in Trenches}

Some ETF Activated Carbon Vessels are slated for trench disposal, but the vessels contain tritium that would pose an inventory limit consumption problem. A UDQ-E (Collard, 2002c) was performed that considered sealing all openings. An SA is planned in FY03.

\subsubsection{UDQ-E's for Trench Geometry Deviations}

When the excavated trench geometry deviated more than 10 percent from the conceptual model a UDQ-E) was prepared. In the first case (Wilhite, 2001) certain trenches were constructed much shorter than evaluated in the conceptual model. In the second case (Cook, 2001) a trench intersected waste from a previously filled trench. In the third case (Cook, 2002a) a trench was constructed shallower than shown in the trench conceptual model. The UDQ-Es provided adjustments to the inventory limits.

\subsubsection{LAW Vault Footprint UDQ-E (FY03)}

The LAW Vault Footprint is conveniently used to define the boundary for a set of five slit trenches and the outline of a single engineered trench. Multiple dimensions for the size of the LAW Vault Footprint were discovered in the PA. This discovery will be investigated.

\subsubsection{UDQ-E for Evaluation of M-Area Glass (FY03)}

An earlier Special Analysis developed inventory limits for vitrified waste from the M-Area. The current activity focuses on auxiliary waste such as the melter, debris and components that were not stated as being included in the initial report.

\subsubsection{Beneficial Reuse Containers UDQ-E (FY03)}

Beneficial reuse containers are manufactured from activated metals. The activated metal will release contaminants more slowly than generic waste, thus reducing groundwater concentrations but increasing residual inventory that intruders can encounter. Some M-Area glass was disposed in beneficial reuse containers, thus this activity will supplement the approved M-Area glass Special Analysis and the FY03 work on the M-Area glass.

\subsubsection{UDQ-E to Evaluate backfill hydraulic properties (FY03)}

The saturated hydraulic conductivity of the various backfill materials before failure is assumed to be either $1 \mathrm{E}-6 \mathrm{~cm} / \mathrm{s}$ or $1 \mathrm{E}-5 \mathrm{~cm} / \mathrm{s}$ within the PA. However, these low values cannot be obtained with current practices for placement of the interim soil covers over slit trenches and the Engineered Trench.

Additionally it is even difficult to obtain these low values in controlled compacted backfill using typical SRS structural backfill borrow pit material. Finally the waste is initially assumed to have the same hydraulic conductivity as the slit trench "clean backfill" or interim soil cover. Therefore this study is required in order to resolve this discrepancy.

\subsubsection{UDQ-E to Evaluate the disposal of Co-60 slugs placed in a DU cask (FY03)}

Co-60 was screened from the groundwater pathway for slit trenches in the PA. These high-concentration slugs and the DU cask itself must be evaluated as a waste source.

\subsubsection{UDQ-E for Engineered Trench \#2 Location (FY03)}

Provide PA requirements for selecting locations to site new Engineered Trenches or new sets of slit trenches. A change in location changes the aquifer flow field and plume interactions. 


\subsubsection{UDQ-E for change in closure concept from kaolin layer to geosynthetic clay liner (GCL) $\underline{(\text { FY03) }}$}

A GCL has a lower saturated hydraulic conductivity, is thinner, has a higher tensile strength, and is less costly to install than a controlled compacted kaolin layer. Therefore the currently assumed kaolin layer will be replaced with a GCL.

\subsubsection{UDQ-E to Potentially evaluate disposal of Cf-252 waste (FY03)}

The waste needs to be better classified to ensure that it is neither mixed waste nor TRU waste. Inventory limits already exist for Cf-252 slit trench disposal, thus unless special circumstances dictate, a UDQ evaluation will not be required.

\subsection{Special Analyses}

Many Special Analyses (SAs) were completed that extended the PA by either establishing new limits or extending existing limits to new situations. In each case a deviation to the base case was developed. In many cases, the deviations were applicable to only one waste stream (e.g., M-Area glass special release rate) and do not affect the general base case. In other cases the deviations do affect the base case (e.g., a change in MCLs). SAs affecting trench disposal that have been completed or are planned are identified and their purpose is presented in the remainder of this section. Changes to the baseline model evaluated in these SAs are summarized in Table 2.

Table 2. Changes to the Baseline Model Evaluated in Special Analyses

\begin{tabular}{|c|c|c|}
\hline Description & Baseline Value & Study Value \\
\hline \multicolumn{3}{|c|}{ Past Special Analyses } \\
\hline M-Area Glass & $\begin{array}{l}\text { No leach rate specified, } \mathrm{Kd} \\
\text { controlled }\end{array}$ & $\begin{array}{l}\text { Low, variable contaminant leach } \\
\text { rate }\end{array}$ \\
\hline High-Concentration I-129 & Low Kd in waste zone & High waste-specific Kd \\
\hline Cellulose Degradation & $\begin{array}{l}\text { Kd independent of cellulose } \\
\text { concentration }\end{array}$ & $\begin{array}{l}\text { Kd varied by cellulose } \\
\text { concentration over space }\end{array}$ \\
\hline New Pu Chemistry & $\mathrm{Kd}$ independent of $\mathrm{Pu}$ speciation & Kd dependent on Pu species \\
\hline Correction and Update of PA Limits & $\begin{array}{l}\text { Original MCLs and literature } \\
\text { values for Kds }\end{array}$ & $\begin{array}{l}\text { New MCLs and some site- } \\
\text { specific Kds }\end{array}$ \\
\hline \multicolumn{3}{|c|}{ FY03 Special Analyses } \\
\hline Air Emissions & Point source & Area source \\
\hline ETF Activated Carbon Vessels & Generic Kd & $\begin{array}{l}\text { Waste-specific } \mathrm{Kd} \text { and delayed } \\
\text { tritium release due to sealing }\end{array}$ \\
\hline $\begin{array}{l}\text { Implement timing of doses to } \\
\text { calculate sums-of-fractions }\end{array}$ & $\begin{array}{l}\text { Sum-of-fractions based on lowest } \\
\text { inventory limit for each nuclide } \\
\text { considering all scenarios } \\
\text { simultaneously }\end{array}$ & $\begin{array}{l}\text { SOF calculated separately for } \\
\text { each scenario. Groundwater } \\
\text { scenario further subdivided by } \\
\text { time intervals. Lowest SOF used }\end{array}$ \\
\hline New Pu trench/vault limits & Literature values for $\mathrm{Kd}$ & Kd based on lysimeter study \\
\hline \multicolumn{3}{|c|}{ Potential Future Work } \\
\hline Subsidence & $\begin{array}{l}\text { Indirectly considered by changing } \\
\text { material properties, limited } \\
\text { sensitivity study varying surface } \\
\text { infiltration }\end{array}$ & $\begin{array}{l}\text { Directly incorporate by varying } \\
\text { waste thickness over time }\end{array}$ \\
\hline $\begin{array}{l}\text { Incorporation of important results } \\
\text { from other studies }\end{array}$ & Not considered or not discovered & $\begin{array}{l}\text { Studied, incorporated as } \\
\text { appropriate - aquifer source node } \\
\text { location, footprint matching, 3D } \\
\text { vadose zone model, etc. }\end{array}$ \\
\hline
\end{tabular}




\subsubsection{M-Area Glass Special Analysis}

A Special Analysis for M-Area glass (Cook and Yu, 2002) was conducted that used a special release rate for the contaminants.

\subsubsection{Slit Trench High-Concentration I-129 Special Analysis}

Multiple waste streams were analyzed (Collard, 2001b) by replacing the generic waste Kd by a laboratorymeasured, waste-specific Kd to establish inventory limits. The Kd range was extended beyond those measured to help provide an equation relating inventory limit to $\mathrm{Kd}$.

\subsubsection{Cellulose Degradation Special Analysis}

Cellulose degradation in wood products can produce dissolved organic carbon that affects Kds. The Special Analysis (Cook and Wilhite, 2000) was based on past laboratory and modeling studies that developed data and methods to adjust inventory limits.

\subsubsection{New Pu Chemistry Special Analysis}

A Special Analysis (Cook, 2002c) of the effect of new plutonium chemistry was conducted that included different $\mathrm{Kds}$ for $\mathrm{Pu}(\mathrm{V})$ and $\mathrm{Pu}(\mathrm{IV})$. This study introduced special simulation effects connected with speciation and colloids.

\subsubsection{Correction and Update of Disposal Limits Special Analysis}

Part of this Special Analysis (Cook, 2002b) combined results from some previous Special Analyses and new MCLs to revise inventory limits.

\subsubsection{Area Source for Air Emissions as Part of the K and L Basin Resins Special Analysis (FY03)}

The air pathway in the PA was analyzed assuming a point source. However, assuming an area source likely will substantially increase the allowable inventory because the area is large relative to the distance to the receptor (about $640 \mathrm{ft}$ by $145 \mathrm{ft}$ for an area vs. $100 \mathrm{~m}$ to the receptor). While the $\mathrm{K}$ and $\mathrm{L}$ Basin Resins Special Analysis addresses waste disposal in the ILV and as CIG, the air results for the CIG should be directly applicable to other trenches.

\subsubsection{Special Analysis for disposal of three ETF Activated Carbon Vessels in trenches (FY03)}

The UDQ evaluation recommended sealing the vessel openings to impede tritium escape. Under these conditions, credit will be taken for 25 years of tritium decay before its release.

\subsubsection{Special Analysis to implement timing of doses to calculate sums-of-fractions (FY03)}

This activity involves two changes to the calculation of sums-of-fractions. First, concentrations at the 100-m well are separated into multiple time intervals. Each time interval will have its own maximum concentration. The maximum concentration for each time interval must be less than or equal to the peak concentration previously predicted, thus the inventory limit for each time interval must be greater than or equal to the PA allowable inventory. The sum-of-fractions is calculated for each time interval, independent of all other time intervals. Simultaneously, a sum-of-fractions is calculated for the other pathways, as applicable. The other pathways include the air pathway, radon, the residential scenario, the agricultural scenario, and the post-drilling scenario.

\subsubsection{Special Analysis to set new Pu trench/vault limits (FY03)}

This Special Analysis will incorporate the results from the Pu lysimeter study that is intended to develop site-specific Pu Kd values for specific Pu oxidation states.

\subsubsection{Subsidence (Future)}

Subsidence in Engineered Trenches continues to be studied with corrosion evaluations and structural models. Results from those studies and other work, such as field studies will be examined to evaluate the effects of the reduction in waste zone thickness over time.

Additionally these activities along with the replacement of the kaolin layer with a GCL should allow the development of improved information on long-term cap performance that can be incorporated in the baseline. For example, rather than instantly assuming cap failure when institutional control ceases, a suitable period of time might be allowed before the failure is assumed to occur. 


\subsubsection{Incorporation of important results from other studies (Future)}

Other studies that are most likely to create changes in the baseline are the aquifer source/observation node study, the size matching of vadose zone and aquifer model cells, and the three-dimensional vadose zone model. All studies will be reviewed to evaluate the need to revise the baseline.

\subsection{Special Studies and Sensitivity Studies}

Many Special Studies and Sensitivity Studies (SSs) were completed that evaluated potential changes to the PA. In each case a deviation to the base case was developed. SSs affecting trench disposal that have been completed or are planned are identified and their purpose is presented in the remainder of this section. Changes to the baseline model evaluated in these Special Studies are summarized in Table 3.

Table 3. Changes to the Baseline Model Evaluated in Special Studies

\begin{tabular}{|c|c|c|}
\hline Description & Baseline Value & Study Value \\
\hline \multicolumn{3}{|c|}{ Past Special Studies } \\
\hline Uncertainty & $\begin{array}{l}\text { Limited to discussion and some } \\
\text { sensitivity studies }\end{array}$ & $\begin{array}{l}\text { Limited probabilistic approach. } \\
\text { Varied natural properties }\end{array}$ \\
\hline Subsidence & $\begin{array}{l}\text { Indirectly considered by changing } \\
\text { material properties, limited } \\
\text { sensitivity study varying surface } \\
\text { infiltration }\end{array}$ & $\begin{array}{l}\text { Local and global surface } \\
\text { infiltration changed extending } \\
\text { previous work. Other work on } \\
\text { structural response. }\end{array}$ \\
\hline Timed Sum-of-Fractions & $\begin{array}{l}\text { Sum-of-fractions based on lowest } \\
\text { inventory limit for each nuclide } \\
\text { considering all scenarios } \\
\text { simultaneously }\end{array}$ & $\begin{array}{l}\text { SOF calculated separately for } \\
\text { each scenario. Groundwater } \\
\text { scenario further subdivided by } \\
\text { time intervals. Lowest SOF used } \\
\text { (see SA for implementation) }\end{array}$ \\
\hline Point Source Study & $\begin{array}{l}\text { Inventory averaged over disposal } \\
\text { unit volume }\end{array}$ & $\begin{array}{l}\text { Concentrated sources of various } \\
\text { sizes of waste at various locations }\end{array}$ \\
\hline Vadose Zone vs. Aquifer Footprint & $\begin{array}{l}\text { Best fit of facility footprint to } \\
\text { existing aquifer model }\end{array}$ & $\begin{array}{l}\text { Aquifer model fit to facility } \\
\text { footprint }\end{array}$ \\
\hline \multicolumn{3}{|c|}{ FY03 Special Studies } \\
\hline $\begin{array}{l}\text { Incorporate vadose zone data in a } \\
\text { three-dimensional trench model }\end{array}$ & $\begin{array}{l}\text { 2D vadose zone model with } \\
\text { aggregated soil zones }\end{array}$ & $\begin{array}{l}\text { Vadose zone monitoring data } \\
\text { used to develop multiple, discrete } \\
\text { soil zones }\end{array}$ \\
\hline $\begin{array}{l}\text { Aquifer Source and Observation } \\
\text { Cell Location }\end{array}$ & $\begin{array}{l}\text { Based on } 99 \% \text { or } 99.9 \% \\
\text { saturation }\end{array}$ & $\begin{array}{l}\text { Other algorithms, e.g., } \sim 25 \text { feet } \\
\text { below trench bottom as in vadose } \\
\text { zone model }\end{array}$ \\
\hline Point Source & $\begin{array}{l}\text { Inventory averaged over disposal } \\
\text { unit volume }\end{array}$ & $\begin{array}{l}\text { "As-filled" waste using WITS } \\
\text { data for inventories of important } \\
\text { nuclides and to help determine } \\
\text { waste locations }\end{array}$ \\
\hline $\begin{array}{l}\text { Model waste layer stabilization and } \\
\text { long term cover systems }\end{array}$ & Waste zone thickness fixed & $\begin{array}{l}\text { Structural analysis of waste zone } \\
\text { thickness including corrosion }\end{array}$ \\
\hline \multicolumn{3}{|c|}{ Future Work } \\
\hline Numerical Dispersion & $\begin{array}{l}\text { Recognized, hydrodynamic } \\
\text { dispersion set to zero to } \\
\text { compensate }\end{array}$ & $\begin{array}{l}\text { Refine mesh or other models to } \\
\text { reduce effects of numerical } \\
\text { dispersion; implement } \\
\text { hydrodynamic dispersion }\end{array}$ \\
\hline Uncertainty & $\begin{array}{l}\text { Limited to discussion and some } \\
\text { sensitivity studies }\end{array}$ & $\begin{array}{l}\text { More extensive variation, } \\
\text { possibly using simpler model and } \\
\text { probabilistic techniques }\end{array}$ \\
\hline
\end{tabular}

\subsubsection{Uncertainty Study}

The initial effort at conducting an uncertainty study (Cook, et al. 2002) for the trenches focused on naturally varying parameters, (e.g., surface infiltration, particle density, porosity, saturated hydraulic conductivity, moisture characteristics, time and duration of cap placement, Kd values for contaminant in 
multiple media, global changes to recharge, global changes to conductivity). That work was preliminary and did not lead to any actual changes in the base case model. Future uncertainty work is planned, possibly using a simpler model.

\subsubsection{Subsidence Studies}

Trench subsidence is partially implied in the current base case. The failed cap stage assumes that the overlying topsoil replaces most of the waste zone.In a sensitivity study (Collard, 2000), infiltration was moderately increased over the entire capped region (the global model) to represent subsidence over a large area. Also as part of that study, infiltration was highly increased over 10 percent of the capped region to represent greater subsidence expected over a smaller area (the local model). Other studies (i.e., corrosion, structural models) representing a waste zone with a deteriorating B-25 box stack are improving the understanding of subsidence.

\subsubsection{Timed Sum-of-Fractions Study}

A Special Study (Collard, 2002b) that considers the effects of time on concentration peaks and thus the sum-of-fractions was conducted in FY02. The current PA method to determine the allowable inventory effectively considers all peak contaminant concentrations to occur simultaneously. However, if the 10,000year analysis period is subdivided into several time intervals, each contaminant will have a separate peak concentration for each time interval, leading to a separate allowable inventory for each time interval. Timed sums-of-fractions can then be calculated for each time interval. A Special Analysis is scheduled for FY03 to help implement the timed sum-of-fraction method.

\subsubsection{Point Source Study}

Point sources refer to wastes that have much higher concentrations than "ideal waste" but that occupy small volumes. "Ideal waste" is defined as waste that simultaneously consumes equal fractions of the inventory limit and the disposal space.

An initial parametric study (Collard, 2002a) was conducted to determine the potential effects of limited volumes of special wastes by modeling them as "point sources." A subsequent Special Study is being conducted to determine the effects of some point sources as they were actually disposed.

\subsubsection{Vadose Zone vs. Aquifer Footprint Independent Report}

An independent study (Collard, 2001a) compared the effects of better matching the vadose zone footprint with the aquifer footprint by using a revised aquifer model with smaller aquifer cell sizes.

\subsubsection{Incorporate vadose zone data in a three-dimensional trench model (FY03)}

DRI has already developed their version of a 3D geological model incorporating results from vadose zone monitoring studies. Thus that model can be modified as needed to provide information on the benefits of a $3 \mathrm{D}$ vadose zone model vs. the current $2 \mathrm{D}$ model. Results from vadose zone monitoring studies were used by DRI.

\subsubsection{Aquifer Source and Observation Cell Location Special Study (FY03)}

Aquifer source cell locations refer to the cells in the aquifer transport model where contamination is introduced or effectively injected. The vadose zone models produce a contaminant flux at the water table representing the mass of contaminant that enters the aquifer. This mass of contaminant is the aquifer source. At the other end of the aquifer flow path the observation cells represent the location of a 100-m theoretical well.

\subsubsection{Point Source Special Study (FY03)}

A previous study examined point sources in a parametric manner. Worst case conditions showed potential problems. The present activity intends to investigate the results for the actual waste as it was disposed in the first set of five slit trenches, i.e., for "as-filled" conditions. This study requires refining the vadose zone and aquifer meshes to match the waste and facility footprints. 


\subsubsection{Model waste layer stabilization and long term cover systems for the engineered trench. (Future)}

This study will incorporate additional information into the PA trench model on subsidence from corrosion studies and structural modeling of the waste layer to determine expected cover performance.

\subsubsection{Numerical Dispersion Study (Future)}

Numerical dispersion results from mathematical operations that can only approximate the advection of contaminants. An initial study of numerical dispersion for a HLW tank farm model showed numerical dispersion increased the peak concentrations by at least a factor of 2. That model examined peak concentrations at seep locations that are over 1 mile away from the source, while the PA models project peak concentrations at 100-m wells. A study on the effect of numerical dispersion for PA models is planned for FY04.

\subsubsection{Uncertainty Study (Future)}

Plans are to extend the earlier uncertainty study, possibly by using a simpler model. 


\section{References}

Collard, L.B. 2000. Subsidence Sensitivity Study for Low-Level Waste in Slit Trenches, WSRC-RP-200000526, Rev. 0, Westinghouse Savannah River Company, Aiken, SC

Collard, L. B. 2001a. Importance of Size Matching in Decoupled, Subsurface Contaminant Transport Models, Proceedings of the Business and Industry Symposium, 2001 Advanced Simulation Technologies Conference, The Society for Modeling and Simulation International, San Diego, CA

Collard, L. B. 2001b. Special Analysis for Disposal of High-Concentration I-129 Waste in Slit Trenches at the E-Area Low-Level Waste Facility, WSRC-TR-2001-00021, Rev. 0, Westinghouse Savannah River Company, Aiken, SC

Collard, L. B. 2002a. Effect of Point Sources in Slit Trenches at the E-Area Low-Level Waste Facility on Groundwater Concentrations, WSRC-TR-2002-0117, Rev. 0, Westinghouse Savannah River Company, Aiken, SC

Collard, L. B. 2002b. Evaluation of a Method to Calculate the Sum-of-Fractions for Multiple Radionuclides that Uses Aquifer Concentrations of Radionuclides that Change with Respect to Time, WSRC-TR-2002-00430, Rev. 0, Westinghouse Savannah River Company, Aiken, SC

Collard, L. B. 2002c. Evaluation of Proposed New LLW Disposal Activity Disposal of ETF Activated Carbon Vessels, WSRC-TR-2002-00339, Rev. 0, Westinghouse Savannah River Company, Aiken, SC

Collard, L. B. 2002d. Software Quality Assurance Plan for the PORFLOW Code, WSRC-SQP-A-00028, Rev. 0, Westinghouse Savannah River Company, Aiken, SC

Cook, J. R. 2001. Discovery of Operational Anomalies in Slit Trench Disposal Operations, WSRC-RP2001-00946, Rev. 0, Westinghouse Savannah River Company, Aiken, SC

Cook, J. R. 2002a. Discovery of Disposal of Low-Level Waste in Slit Trench Segments Shallower than Analyzed in Performance Assessment, WSRC-TR-2002-00249, Rev. 0, Westinghouse Savannah River Company, Aiken, SC

Cook, J.R., 2002b. Special Analysis: Correction and Update of E-Area Disposal Limits. WSRC-TR-200200047, Rev. 2. Savannah River Laboratory, Westinghouse Savannah River Company, Aiken, SC., May 2.

Cook, J. R. 2002c. Special Analysis, Effect of New Plutonium Chemistry on SRS Trench Disposal Limits, WSRC-TR-2002-00154, Rev. 0, Westinghouse Savannah River Company, Aiken, SC, September 30.

Cook, J. R., A. D. Yu, 2002. Special Analysis: Disposal of M-Area Glass in Trenches, WSRC-TR-200200337, Rev. 1, Westinghouse Savannah River Company, Aiken, SC

Cook, J. R. and E. L. Wilhite, 2000. Special Analysis: Updated Analysis of the Effect of Wood Products on the Trench Disposal Limits at the E-Area Low-Level Waste Facility, WSRC-RP-2000-00523, Rev. 0, Westinghouse Savannah River Company, Aiken, SC

Cook, J. R. , L. B. Collard, G. P. Flach, P. L. Lee, 2002. Development of Probabilistic Uncertainty Analysis Methodology for SRS Performance Assessments Maintenance Plan Activities, WSRC-TR-200200121, Rev. 0, Westinghouse Savannah River Company, Aiken, SC

McDowell-Boyer, L., A.D. Yu, J.R. Cook, D.C. Kocher, E.L. Wilhite, H. Holmes-burns, K.E. Young. 2000. Radiological Performance Assessment for the E-Area Low-Level Waste Facility. WSRC-RP-94218, Rev. 1. Westinghouse Savannah River Company, Savannah River Site, Aiken, SC., January 31, 2000.

Martin Marietta Energy Systems, Inc. and EG\&G Idaho, Inc. 1994. Radiological Performance Assessment for the E-Area Vaults Disposal Facility. WSRC-RP-94-218, Rev. 0. Westinghouse Savannah River Company, Savannah River Site, Aiken, SC., April 15. 
Wilhite, E. L. 2000a. Evaluation of Proposed New LLW Disposal Activity Disposal LLW in a MegaTrench rather than in Slit Trenches, WSRC-RP-2000-00217, Rev 0, Westinghouse Savannah River Company, Aiken, SC

Wilhite, E.L. 2000b. Evaluation of Proposed New LLW Disposal Activity Disposal of Compacted Job Control Waste, Non-Compactible, Non-Incinerable Waste, And Other Wasteforms in Slit Trenches, WSRCRP-2000-00218, Rev 0, Westinghouse Savannah River Company, Aiken, SC

Wilhite, E. L. 2001. Evaluation of Proposed New LLW Disposal Activity: Disposal of Low-Level Waste in Slit Trenches Shorter Than Analyzed in Performance Assessment, WSRC-RP-2001-00947, Rev. 0,

Westinghouse Savannah River Company, Aiken, SC 